\title{
An Investigation of Customer Accounting Systems as a Source of Sustainable Competitive Advantage
}

Holm, Morten; Kumar, V.; Plenborg, Thomas

\author{
Document Version \\ Accepted author manuscript \\ Published in: \\ Advances in Accounting \\ DOI: \\ 10.1016/j.adiac.2015.12.002 \\ Publication date: \\ 2016 \\ License \\ CC BY-NC-ND
}

Citation for published version (APA):

Holm, M., Kumar, V., \& Plenborg, T. (2016). An Investigation of Customer Accounting Systems as a Source of Sustainable Competitive Advantage. Advances in Accounting, 32, 18-30.

https://doi.org/10.1016/j.adiac.2015.12.002

Link to publication in CBS Research Portal

\section{General rights}

Copyright and moral rights for the publications made accessible in the public portal are retained by the authors and/or other copyright owners and it is a condition of accessing publications that users recognise and abide by the legal requirements associated with these rights.

\section{Take down policy}

If you believe that this document breaches copyright please contact us (research.lib@cbs.dk) providing details, and we will remove access to the work immediately and investigate your claim.

Download date: 26. Apr. 2023
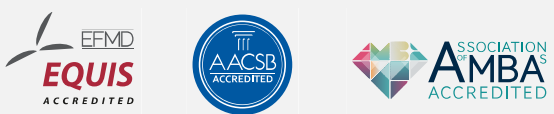


\title{
An Investigation of Customer Accounting Systems as a Source of Sustainable Competitive Advantage
}

\author{
Morten Holm, V. Kumar, and Thomas Plenborg
}

Journal article (Post print version)

Cite: An Investigation of Customer Accounting Systems as a Source of Sustainable Competitive Advantage. / Holm, Morten; Kumar, V.; Plenborg, Thomas. In: Advances in Accounting, Vol. 32, 03.2016, p. 18-30.

\section{DOl: 10.1016/j.adiac.2015.12.002}

Uploaded to Research@CBS: September 2016

(ㄱ 2016. This manuscript version is made available under the CC-BY-NC-ND 4.0 license

http://creativecommons.org/licenses/by-nc-nd/4.0/ 


\title{
An investigation of customer accounting systems as a source of sustainable competitive advantage
}

\begin{abstract}
A B S T R A C T
This study examines whether using customer accounting systems for resource allocation purposes is a source of sustainable competitive advantage. Based on a longitudinal data set comparing the performance of firms that adopt customer accounting and their industry benchmarks, we find that financial performance increases post adoption, leading to significant abnormal positive performance vis-à-vis average industry benchmarks (4-5 \%points ROA difference) in the first two years following the adoption. However, we also show that this effect deteriorates over time, suggesting that the adoption of management accounting systems is a source of temporary rather than sustainable competitive advantage. The results are robust to other strategic events around the time of adoption, different matching of peers, and the influence of other factors that could be expected to influence firm performance. We discuss the implications of these findings for management accounting research and practice.
\end{abstract}

Key words: Customer accounting; Management accounting systems; Sustainable competitive advantage; Dynamic capabilities; Performance 


\section{An investigation of customer accounting systems as a source of sustainable competitive advantage}

\section{Introduction}

Generating superior financial performance by exploiting sources of sustainable competitive advantage is an everlasting quest for commercial enterprises around the world. The role of management accounting in this endeavor is still under debate. Some have argued that management accounting systems do not provide unique competitive advantage per se, but rather act as a support mechanism for other "more important things” (Granlund \& Lukka, 1998; Porter, 1996). Yet empirical evidence has emerged to support the proposition that management accounting may play a more pivotal part in firms' competitive positioning, by demonstrating the positive impact on financial performance of implementing strategic management accounting techniques such as Activity-Based Costing (Cagwin \& Bouwman, 2002; Kennedy \& Affleck-Graves, 2001) and the Balanced Scorecard (Crabtree \& DeBusk, 2008; Davis \& Albright, 2004).

However, even if there is a consensus that - one way or another - management accounting systems can lead to competitive advantage, there has been no agreement about whether this advantage will generally be temporary or sustainable. Some argue that cost information may lead to sustainable competitive advantage if it facilitates, e.g., more efficient use of resources or increased value for customers (Cinquini \& Tenucci, 2010). However, Ahrens and Chapman (2006) suggest that the performance reporting and calculative elements of management accounting techniques such as The Balanced Scorecard and Activity-Based Costing cannot be sources of sustainable competitive advantage per se, as these techniques are purely information-providing, and are generally too easy to imitate. This inimitability issue is particularly noteworthy, as imitability arguably plays an important part in determining the sustainability of competitive advantage in competitive markets where the easy imitation of capabilities entails the more rapid dissipation of abnormal returns (Barney, 1991; Teece, Picano \& Shuen, 1997).

This paper investigates whether management accounting systems can be a source of competitive advantage and deliver superior financial returns which are sustainable over the long term, i.e. whether any abnormal returns they yield are in danger of being 'competed away' over time. We deploy a longitudinal adapted event study methodology to study the adoption of Customer Accounting (CA) systems for resource allocation purposes. Although the event study methodology was originally designed for capital market studies it has also proved to be useful in numerous investigations of the performance effects of strategic management accounting techniques such as Total Quality Management (Easton \& Jarrell, 1998), Economic Value Added (Cordeiro \& Kent, 
2001), Activity-Based Costing (Kennedy \& Affleck-Graves, 2001), Just-in-time (Kinney \& Wempe, 2002), and The Balanced Scorecard (Crabtree \& DeBusk, 2008).

Customer Accounting and particularly Customer Profitability Analysis (CPA) have been relevant topics to management accounting researchers and practitioners for quite some time. Traditionally, the topics related to CA have received most attention in the marketing domain due to the customer's pivotal position in the marketing discipline. However, the potential of management accountants taking an active part in customer profitability management alongside their marketing colleagues is continuously highlighted by researchers (Foster \& Young, 1997; McManus \& Guilding, 2008) and practitioners (CIMA 2008), and leading professional bodies of management accountants have included the topic of customer accounting/profitability/value in their series of comprehensive guidelines on important accounting topics (Epstein \& Yuthas, 2008; IMA, 2010).

Based on a sample of 53 firms who reportedly adopted CA systems for resource allocation purposes at some point in time between 1997 and 2009, we find that their adoption leads to increased industry-adjusted financial performance in the first two years after implementation. Moreover, we find that this performance is significantly higher than average industry returns (45\%-points difference in ROA), suggesting that CA adopters achieve a significant short-term competitive advantage. However, our data also reveals that these abnormal returns disappear over time, suggesting that the competitive advantage achieved is not sustainable in the long term. Importantly, OLS regression analysis also shows that our results hold when controlling for other important determinants of firm financial performance. Moreover, the results are robust to the potential influence of major strategic events around the time of CA adoption and to deploying a matched sample design where CA adopters are matched with declared non-adopters from our gross sample. Additionally, analyses of the drivers of ROA demonstrate that the effects of CA system adoption were strong on operating profit margin and moderate on asset turnover ratio but had no significant effect on market share.

The paper contributes to research in management accounting in several ways. First - to the best of the authors' knowledge - this is the first study to investigate the longer term performance effects of adopting and implementing management accounting systems with the aim of determining whether any short-term impact on performance can be sustained. Our findings thus expand on prior studies on the merits of management accounting systems that have demonstrated positive performance effects in the years following their adoption. We develop theoretical arguments that competitive imitation plays an important part in explaining the diminishing long term performance effects, but acknowledge that other factors such as intra-organizational factors may play a part as well. 
Our results also have implications for research methods into the performance effects of management accounting techniques. If the performance differential varies with time, studies that fail to compare the performance of adopters at similar stages of the management accounting system adoption lifecycle are very likely to produce inconclusive or biased results. This is likely to be particularly troublesome in cross-sectional research designs, and may play some part in explaining why prior cross-sectional research on the performance effects of management accounting techniques such as Activity-Based Costing have shown mixed results (Banker, Bardhan \& Chen, 2008).

Moreover, we expand on marketing accountability research by providing novel large-sample longitudinal evidence on the performance effects of customer profitability models. More specifically, we offer empirical generalizations of the indicative evidence presented in prior case demonstrations in the marketing literature (e.g., Kumar, Venkatesan, Bohling \& Beckmann, 2008; Kumar \& Shah, 2009; Ryals, 2005).

The rest of the paper is organized as follows. First, we develop our hypotheses based on theories from the accounting, marketing, and general management literatures. We then describe our research method and data sample, and then present an analysis of our results, including tests of the robustness of our findings. The paper is rounded off by a discussion and conclusion, in which its limitations are also discussed.

\section{Theoretical background and hypotheses}

\subsection{Customer Accounting}

Based on early works on customer profitability models (e.g., Berger \& Nasr, 1998; Dwyer, 1997; Kaplan \& Cooper, 1998, pp. 183-89; Noone \& Griffin, 1999; Smith \& Dikolli, 1995), Guilding and McManus (2002) introduced and defined the comprehensive Customer Accounting (CA) concept: "Customer Accounting includes all accounting practices directed towards appraising [the] profit, sales, or present value of earnings relating to a customer or group of customers”. This definition corresponds well with the growing consensus in the marketing literature that draws a distinction between two paths to quantifying customers' financial value: the retrospective Customer Profitability Analysis (CPA) approach, with its origin in the accrual conventions of the accounting literature, and the prospective Customer Lifetime Value (CLV) approach, based on the financial net present value principle (Pfeifer, Haskins \& Conroy, 2005). We therefore characterize Customer Accounting techniques as any CA technique that measures individual customers' and/or customer 
segments' contributions to firm profitability, whether in the past, present or future.

CA systems are used for a variety of resource planning and decision purposes, ranging from differentiated pricing and service levels (e.g., credit terms, discount policies, delivery terms, ordering routines, sales visits and account team time allocation, product customization, financing opportunities etc.) according to the financial contributions different customers make to firm profitability (Everaert, Bruggeman, Sarens, Anderson \& Levant, 2008; Guerreiro, Bio, Vazquez \& Merschmann, 2008; Kaplan \& Cooper, 1998, pp 183-89; Niraj, Gupta \& Narasimhan, 2001; Ryals, 2005; Smith \& Dikolli, 1995); the allocation of marketing resources in general (Homburg, Droll \& Totzek, 2008), and to customer acquisition vs. retention purposes (Blattberg \& Deighton, 1996; Blattberg, Getz \& Thomas, 2001; Reinartz, Thomas \& Kumar, 2005); the allocation of promotion expenditures (Berger \& Nasr, 1998; Berger \& Bechwati, 2001), marketing mix decisions (Mulhern, 1999); and the number of marketing contacts (e.g., direct mail campaigns) effected across different channels (Kumar, Shah \& Venkatesan, 2006). All these planning purposes relate to the prioritization of customer relationships according to the current and future profitability different customers yield, and are thus expected to lead to the more efficient utilization of firm resources.

\subsection{H1 Customer accounting and competitive advantage}

It has been suggested that customer relationships are intangible assets that should be managed according to their asset value, i.e., the value they contribute over the lifetime of customers' business with the firm (e.g., Gupta \& Lehmann, 2005; Hogan, Lemon \& Rust, 2002; Srivastava, Shervani \& Fahey, 1998). Customer asset management is a proactive approach, with firm actions targeted at acquiring, retaining and expanding those customer relationships that are most valuable to the firm over their lifetime (Berger et al., 2002; Bolton, Lemon \& Verhoef, 2004). Consequently, accounting for customer relationship profitability becomes a pivotal element in customer asset management.

The firm's capability in managing its customers as assets can necessitate the ongoing reconfiguration of firm resources based on the generation and dissemination of customer intelligence across the organization's customer-facing functions. Following Zollo and Winter (2002), Heimeriks, Schijven and Gates (2012, p. 704) define dynamic capabilities as “a learned and stable pattern of collective activity through which an organization systematically generates and modifies its operating routines in pursuit of improved effectiveness”. Based on this we argue that customer asset management can be classified as a dynamic capability, and that customer asset management capabilities are comparable to other dynamic capabilities that have been studied in the 
management literature, such as those of managing acquisition processes (Heimeriks et al., 2012; Zollo \& Singh, 2004), and corporate alliances and joint ventures (e.g., Kale \& Singh, 2007; Keil, 2004).

Dynamic capabilities involve the potential to change resources, routines and competences to suit the situation at hand, and there is general agreement in the management literature that operational capabilities and functional competencies constitute tangible outcomes of dynamic capabilities (Easterby-Smith \& Prieto, 2008). Thus competitive advantage does not emerge directly from dynamic capabilities per se - rather it is the new (re-)configurations of resources and operational routines and processes resulting from the exercise of dynamic capabilities that drive competitive advantage and, ultimately, superior financial returns (Eisenhardt \& Martin, 2000; Winter, 2003; Zahra, Sapienza \& Davidsson, 2006). So CA systems for resource allocation purposes can be thought of as comprising operational/functional competencies (Cepeda \& Vera, 2007) that lead to tangible outcomes of (dynamic) customer asset management capabilities. CA systems assign financial values to customer relationships in order to prioritize them according to their impact on firm profitability and ultimately shareholder value - so such systems are the cornerstone of a firm's ability to execute customer asset management strategies.

Case-based research has consistently supported the proposition that CA system adoption leads to improved firm performance. Kumar et al. (2008) found that a high tech manufacturer was able to grow its sales by $\$ 20$ million, without investing new resources but simply reallocating marketing and sales resources according to customers' financial value. Kumar and Shah (2009) demonstrated how a retailer and a manufacturer implemented profitability-based customer management strategies to outperform both their peers and the S\&P500 Index in the stock market. Anecdotal evidence has indicated similar results of CA system implementations in financial services (Ryals, 2005), and in industrials (Kaplan \& Cooper, 1998, 183-89).

These theoretical arguments and case-based evidence take us to our first hypothesis:

H1: The adoption of Customer Accounting practices for resource allocation purposes provides a competitive edge that leads to abnormal positive financial performance vis-à-vis competition.

\subsection{H2 The sustainability of CA-based competitive advantage}

One important implication of developing and implementing CA systems to quantify the financial benefits gained from customer relationships is that the operational customer management routines and processes that are the tangible materializations of dynamic customer asset management 
capabilities are more easily transferred across the organization in a replication that Teece et al. (1997) defined as involving “...transferring or redeploying competences from one concrete economic setting to another” (Teece et al., 1997, p. 525). During this replication process the CA system acts as a codification artifact, with codification defined as "the expression of knowledge in a standardized, fixed form” (Zollo \& Winter, 2002). During the process of developing, implementing and using CA systems, knowledge is codified in Customer Relationship Management (CRM) systems, customer profitability tools, resource allocation guidelines etc. Hence, CA system implementations not only create new knowledge but also make knowledge more readily available (in a fixed form) to other organizational members. Furthermore, tacit knowledge (e.g., regarding existing customer management processes) can be converted to explicit knowledge over time (Håkanson, 2007), as competences are gradually transferred to propositional knowledge (Balconi, Pozzali \& Viale, 2007). Thus CA codification processes can facilitate the diffusion of tacit knowledge without the transfer of people (Teece et al., 1997), and generally facilitate the coordination and handling of complex processes across organizations (Håkanson, 2007; Zollo \& Winter, 2002).

Codification is therefore an inherent component in CA system development and implementation processes. The replication of customer asset management routines and competences across multiple entities is a key benefit of codification, as it facilitates the sharing of best practices in customer asset management across large and diversified organizations. However, this replicability involves a troubling dilemma, which has been the subject of substantial investigation in management research on the sustainability of competitive advantage. Replication is required in order for firms to transfer knowledge rapidly enough to grasp market opportunities, but at the same time it entails the threat of imitation from competitors (Coff, Coff \& Eastvold, 2006; King \& Zeithaml, 2001). The more explicit the knowledge and the more unambiguous the causality between specific competences and firm outcomes, the higher is the risk that competitors will be able to gain access to that knowledge and so imitate the routines and processes that generate competitive advantage (Kogut \& Zander, 1992; Rivkin, 2001; Zander \& Kogut, 1995). Thus, as CA implementations inevitably entail codifying the understanding of causal relationships between firms' resource allocation efforts, customer behaviors, customer profitability outcomes and firm financial performance, causal ambiguity is reduced, and knowledge becomes increasingly mobile. The easier customer asset management knowledge is to copy, the more likely it is to be disseminated to competitors (e.g., via consultants, transfer of employees etc.), (King \& Zeithaml, 2001).

The speed of competitive imitation will vary across business contexts, and the ability to control this diffusion of inter-organizational knowledge may counter the erosion of competitive advantage 
(Kogut \& Zander, 1992). However, imitation differs from replication in the important sense that "[w]hereas technology transfer is concerned with adapting the technology to the least capable user, the threat of imitation is posed by the most capable competitors” (Kogut \& Zander, 1992, p. 392). So when an explicit CA industry recipe diffuses across organizational boundaries, the question of imitation merely becomes one of time: how fast can competitors imitate the explicit knowledge 'made available' by the CA template, internalize that knowledge, and develop the tacit skills required to successfully exploit the customer asset management capabilities facilitated by the CA system?

All this leads to a second hypothesis:

H2: The abnormal positive financial performance effect that follows the adoption of Customer Accounting practices for resource allocation purposes is not sustainable in the long term.

\section{Research Method}

\subsection{Sample selection, data collection and variable measurement}

The data for this study on the short- and long-term performance effects of CA system adoption come from two main sources: primary survey data to establish what year the firms adopted CA systems for resource allocation purposes (if at all), and secondary archival accounting data to measure the adopters' industry-adjusted financial performance over time.

As decisions to adopt new management accounting techniques are rarely declared publicly, we developed a mail questionnaire survey to establish whether and when firms had adopted CA systems for resource allocation purposes. We hereby adopt a measurement approach similar to previous event studies investigating the performance effects of adopting advanced management accounting techniques (e.g., Crabtree \& DeBusk, 2008; Kennedy \& Affleck-Graves, 2001; Kinney \& Wempe, 2002). A dichotomous measurement approach for the adoption of CA systems is required in order to apply the event study method and due to our fairly limited sample size we were unable to split our sample into subsamples of varying extent of CA usage.

The questionnaire contained a detailed definition of customer accounting systems, based on a thorough review of CA system literature, to mitigate validity issues. We carefully defined both the retrospective Customer Profitability Analysis (CPA) method (Pfeifer et al., 2005) and the prospective Customer Lifetime Value (CLV) method (Gupta et al., 2006) and asked informants whether they were using either of these methods for resource allocation purposes in their organizations. If (and only if) they stated that they used CPA and/or CLV we asked them to report 
the specific year when they started using CPA and/or CLV, and included the option to skip this question if they had no knowledge of the timing of this event (See questionnaire in Appendix A).

Survey data was collected in Denmark during the fall and winter of 2010/11 ${ }^{1}$.We targeted the top 1,000 largest Danish firms (ranked by revenues) as our sampling frame, as larger firms are expected to be more inclined to adopt sophisticated decision-making tools (Bjørnenak, 1997). We aimed for high level commercial executives (sales and marketing directors or managers) as our survey population (Van der Stede, Young \& Chen, 2005), as such managers are more likely to be in charge of making their organization's regular strategic and operational customer management decisions, and so can be expected to have the most informed perspectives on their firms' use of CA systems for resource allocation purposes.

We followed Dillman's (1999) guidance on the design and administration of the survey, and collected information on commercial executives manually. We excluded 209 firms mainly because contact information was unavailable or firm policies forbade disclosure of employee e-mail addresses, which left us with a survey population of 791 potential informants. These managers were contacted by e-mails which included a personalized cover letter and a hyperlink to the online questionnaire.

To minimize the risk of non-sampling errors in terms of response error we tested the questionnaire prior to launch with three test-groups - six academic colleagues from marketing and accounting departments, nine business managers mainly from marketing/sales, and five management consultants. An important purpose of this pre-test was to validate the CPA and CLV constructs in the survey, and we therefore refined our CPA and CLV definitions according to their responses.

To minimize the risk of non-sampling errors in terms of non-response error, we conducted three rounds of follow-up e-mailings to all informants during the month after distributing the questionnaire, which yielded a gross sample of 195 questionnaires with sufficient detail to facilitate further analysis (i.e., a response rate of 25 percent). Although this is an acceptable response rate for cross-sectional samples (Churchill, 1991), we analyzed the sample for non-response bias (not reported) using Armstrong and Overton’s (1977) extrapolation method to compare early and late responses. We compared the mean adoption rate and the average time since adoption for early and late responses: as neither of these analyses revealed any significant differences between the two groups, we did not find any evidence of systematic non-response bias.

Of the 195 questionnaires returned, 82 informants responded that their firm used CA systems for resource allocation purposes - an adoption rate of 42 percent. Only one firm responded as having tried using a CA system for resource allocation purposes but abandoned it again. This single 
observation was excluded from the data set. Of these 82 CA adopters, 19 informants did not disclose the year of adoption, and financial data was not available in 10 other cases, so these observations were excluded, leaving 53 applicable CA adopters as the net sample we used for further investigation. Figure 1 outlines the development in CA adoption over time, showing the years each of these firms started using CA. The development follows an S-curve, which is a common trait for the diffusion of innovations over time (Malmi, 1999).

\section{$<$ INSERT FIGURE 1 ABOUT HERE >}

Table 1 outlines the composition of the sample firms in terms of industry sector, firm size $\mathrm{e}^{2}$ and informant positions.

It is worth noting that a broad cross-section of industries are represented in the sample, although manufacturing, retail and wholesale firms dominate. In terms of size, approximately two thirds of the firms (64 percent) had less than DKK 1 Billion in annual revenues in the year of adoption, with the median figure being DKK 674 Million. However, the mean revenue was approximately DKK 3 Billion, suggesting that the sample includes a few substantially larger firms. Finally, the vast majority of informants were directors or managers with commercial responsibilities (87 percent of the informants who disclosed their current job titles), which corresponds well with our objective of targeting a survey population of senior commercial executives.

\section{$<$ INSERT TABLE 1 ABOUT HERE >}

We collected archival financial performance data from the ORBIS accounting database for each of the 53 CA-adopters (as well as for all other firms in their industry). CA is expected to influence (a) revenues (e.g., through growth generated by the allocation of more marketing resources to the most profitable customers, customer relationship-based price discrimination etc.), (b) operating profit (e.g., through optimization of customer service resources along the supply chain, focusing sales force time on more profitable customer accounts etc.), and (c) assets on the balance sheet (e.g., through differentiated net working capital requirements across customers). Consequently, we decided to apply Return On Assets (ROA) as we needed a comprehensive measure of firm performance that captures revenue, cost, and balance sheet effects of CA implementations. ROA is applicable for several other reasons. First, only a very small fraction of Danish firms are listed on a stock exchange. Consequently, targeting listed companies would entail a severe risk of ending up with too small a sample - thus using stock returns was not an option. Second, ROA is the most commonly used measure for studying accounting-based measures of operating performance (Barber \& Lyon, 1996), and has been used as firm performance measure in evaluations of the impact of 
similar customer information systems such as the impact of Customer Relationship Management (CRM) on firm performance (e.g., Reinartz, Krafft \& Hoyer, 2004; Vorhies, Orr \& Bush, 2011) as well as the impact of Activity-Based costing techniques on firm/plant performance (e.g., Kennedy \& Affleck-Graves 2001; Ittner, Lanen \& Larcker 2002; Banker et al. 2008). We calculated ROA as operating profit (EBIT) relative to total assets (at the year-end) for all non-financial firms in the sample (49). For the four firms in the 'Financial Institutions and Real Estate' sector we used Return On Equity (ROE) instead, as ROA is rarely a valid measure of such firms' financial performance. ${ }^{3}$

Industry benchmark performance levels for each of the 53 sample firms were identified based on the firms' 3-digit NACE industry codes ${ }^{4}$, a procedure that yielded 40 different industry benchmarks. This technique of comparing firm performance with an average industry benchmark is a common procedure in accounting-based event study research (Barber \& Lyon, 1996). We calculated the value-weighted mean ROA/ROEs for all the firms within each industry as this put more weight on larger firms based on the assumption that these firms will be the most dominant competitors, but also because our sample was drawn from a survey population consisting of the largest firms in Denmark. Industry-adjusted ROA was computed over the relevant time frame, i.e. going back to the year before the adoption of CA systems for resource allocation purposes through to the latest available accounting year (2012). Those firms that are allowed not to disclose revenues in the annual report by the Danish Financial Statement Act were excluded from the industry benchmarks. We hereby eliminate a number of the smallest firms. This was necessary in order to establish unbiased industry benchmarks for the purpose of one of our robustness tests, where ROA was decomposed into operating profit margin and asset turnover ratios, both of which rely on revenues.

Table 2 outlines the number of firms within each of the 40 benchmarked industries. As the table shows, the numbers of firms within the sample firms' industries over the period exceeded five for all but three (NACEs 244, 492, and 613) of our 53 observations. In order to mitigate any potential bias due to low sample size in benchmark industries we used the 2-digit NACE code as the relevant benchmark for firms in those three industries, an approach used in similar studies using industry benchmarks (e.g., Barber \& Lyon, 1996).

$<$ INSERT TABLE 2 ABOUT HERE $>$ 


\subsection{Performance analysis}

To assess the effects of using CA systems on firm performance, we applied the principles of the event study methodology. Although the event study method was originally designed to investigate the impact of unambiguously defined events on firms' market capitalization and/or stock prices (MacKinlay, 1997), this method has also proved to be useful in studies into the performance effects of management accounting techniques such as The BSC (Crabtree \& DeBusk, 2008), ABC (Gordon \& Silvester, 1999; Kennedy \& Affleck-Graves, 2001), Capital Budgeting (Haka, Gordon \& Pinches, 1985), TQM (Easton \& Jarrell, 1998), EVA (Cordeiro \& Kent, 2001), and JIT (Kinney \& Wempe, 2002) (see Table 3).

$<$ INSERT TABLE 3 ABOUT HERE>

Capital market studies are fundamentally different from the current study, in the sense that whereas capital market studies usually investigate daily observations (stock prices), we use accounting performance and so only have annual observations. The significant time lag between the implementation of management accounting systems and their effects on performance (Kennedy \& Affleck-Graves, 2001) is an argument for applying extremely long windows in these types of adapted event studies. Moreover, it is often very difficult, and arguably pointless, to identify the exact day or month when firms officially adopted their CA systems, which again is an argument for deploying a modified event study design based on annual observations. It is also likely that the full effects of CA systems may not be seen in the year of their adoption, as such implementations may take a fairly substantial amount of time to materialize - so we do not expect to see the full effect of CA systems until the first full year after the year of adoption.

In order to test our hypotheses we first ran preliminary univariate t-tests comparing mean performance at different points in time prior to and post adoption. We consistently performed paired t-tests to look for differences in our 53 sample firms' performance at different points in time (dependent observations). We follow Barber \& Lyon (1996) in also reporting the results of the Wilcoxon signed rank test comparing medians across the samples, as the presence of some outliers in the data often results in accounting performance figures not fulfilling normal distribution assumptions. Subsequently, we performed an OLS regression analysis in order to control for other factors that have consistently been shown to influence firm performance. 


\section{Results of hypotheses tests}

\subsection{Univariate analyses}

Hypothesis 1 (H1) states that CA adoption will lead to increased financial performance, taking CA adopters to performance levels that are significantly higher than industry benchmarks. To test this relationship average firm performance was compared with average industry performance over the entire time-period to determine whether the sample firms' ROA were significantly above the industry benchmark in the years following their adoption of CA techniques (Table 4). As Table 4 shows, firm ROA is not significantly different from average industry ROA in any of the years prior to adoption (Pre adoption -2 and -1) or in the year of adoption itself. This is important as it indicates that our sample on average performed on par with their industry benchmarks prior to adoption which is a prerequisite for performing accounting-based event study research (Barber \& Lyon, 1996). However, a significant positive difference between firm and average industry ROA can be identified in the two following full years (Post adoption +1 and +2 ). This difference is both economically significant (a mean 4-5\%-point difference in ROA) and statistically significant, both in terms of the t-test $(p<0.05)$ and the Wilcoxon signed rank test $(p<0.05)$. Moreover, additional tests show a significant increase in industry-adjusted ROA from Pre adoption -1 to Post adoption $+1(p<0.05)$ and to Post adoption $+2(p<0.05)$ suggesting that CA leads to significant improvements in firm performance. These findings support $H 1 .^{5}$

\section{$<$ INSERT TABLE 4 ABOUT HERE >}

Hypothesis $2(H 2)$ proposes that abnormal positive industry-adjusted performance resulting from implementing CA is not sustainable in the longer term. To test this relationship, we compared the firms' industry-adjusted ROA in the three years following their CA adoption with their long term industry-adjusted ROA to determine whether any significant abnormal performance effects achieved were sustained over the longer term (Table 5). Table 4 also reports mean ROA for CA adopters vs. industry average ROA in the longer term, i.e., four and five years after adoption as well as for the year $2012 .{ }^{6}$ As it shows, there is no longer a significant difference between CA users and industry benchmarks in those years or in 2012, suggesting that the competitive advantage initially offered by the adoption of CA no longer exists.

Table 5 outlines industry-adjusted ROA for CA users in each of the three years following the year of adoption (Post Adoption +1, +2, and +3) vs. longer term post adoption benchmarks (Post Adoption +4 and +5 as well as 2012). The table shows that there is a significant negative difference 
between industry-adjusted ROA in the three years following CA adoption and the longer term benchmarks, the differences being particularly marked between Post Adoption +1 and +2 and Post Adoption +5 and 2012. This evidence indicates that the financial performance of firms adopting CA systems for resource allocation purposes will decline again in the longer term towards industry norms - thus supporting our second hypothesis $(H 2)$.

\section{$<$ INSERT TABLE 5 ABOUT HERE >}

\subsection{Regression analysis}

A potential issue in event study research is the ability to isolate the effect of the focal event from other factors that can be expected to influence firm performance. To mitigate this we performed an OLS regression analysis where Industry-adjusted ROA was regressed on CA adoption and five factors that have all consistently been shown to be associated with firm performance in empirical studies (Capon et al. 1990): (1) Industry concentration (positive association expected); (2) Firm market share (positive association expected); (3) Firm growth (positive association expected) (4) Firm size (no expected direction); and (5) Firm leverage (negative association expected). Industry concentration (INDCONC) is measured by the Herfindahl-Hirschman Index (HHI) - a concentration ratio summing the squared market shares across industry firms. Market share (MSHARE) is the firm's revenues as a proportion to industry sales. Revenue growth (GROWTH) is last year's growth in firm revenues. Firm size (SIZE) is the natural logarithm to the current year's revenues; and Firm leverage is measured as the book equity ratio (EQRATIO) i.e. equity divided by total assets. The dependent variable in the regression model is industry-adjusted ROA per year (INDADJROA). Using industry-adjusted ROA allows comparisons across different points in time. The regression model can thus be specified as follows:

$$
\begin{aligned}
& \text { (1) } \text { INDADJROA }_{t}=\alpha+\beta_{1} \text { CA }_{t}+\beta_{2} I N D C O N C+\beta_{3} \text { MSHARE }_{t}+\beta_{4} \text { GROWTH }_{t} \\
& +\beta_{5} \mathrm{SIZE}_{t}+\beta_{6} \mathrm{EQRATIO}_{t}+\varepsilon
\end{aligned}
$$

In order to capture the effect post adoption we ran the same model for each of the five years following CA adoption (CA). The model compares industry-adjusted ROA after adoption (CA = ' 1 ') with industry-adjusted ROA two full years before adoption (CA = '0') across the entire sample while controlling for the other factors as specified earlier. ${ }^{7}$ This way we can compare performance two years before CA adoption with performance the first five years after adoption, one year at the 
time, while controlling for other factors that are expected to influence firm performance. Given our hypotheses and univariate analyses we would expect to see a significant effect of CA in the first two years after adoption and no significant effect in the next three years.

The results of model (1) are presented in Table 6. We observe that the model explains between $13-19 \%$ of the variation in the data and is significant based on F-tests $(p<0.01)$. We also observe a statistically significantly positive association between $C A$ and INDADJROA in the first and the second year $(p<0.10)$ following adoption but not between CA and INDADJROA in the years 3-5. Moreover, the economic significance appears to be declining over time with abnormal industryadjusted ROA in the region of 3 percentage-points higher the first two years after adoption than before adoption. These results supports both our hypotheses suggesting that competitive advantage is achieved in the short term but deteriorates over time. Moreover, the difference between preadoption and post-adoption financial performance appears to be comparable to the effects observed in our univariate analyses. This analysis also indicates that the performance improvement is an effect of CA adoption rather than other industry and firm specific performance effects. Finally, the control variables INDCONC, MSHARE and GROWTH are all statistically significant and in the expected direction whereas EQRATIO is not. Firm size is only significantly associated with firm performance in one of the five models $(p<0.10)$. This corresponds well with the inconclusive findings by Capon et al. (1990) in their meta study of determinants of firm financial performance.

Summing up, our regression analysis provides evidence that the improvement in performance after CA adoption and the long-term deterioration of abnormal returns indicated in our univariate analyses cannot be solely attributed to confounding factors such as market power, stronger growth or industry concentration. ${ }^{8}$

$<$ INSERT TABLE 6 ABOUT HERE $>$

\section{Robustness tests and additional analyses}

In order to corroborate our findings we performed three additional analyses.

\subsection{Influence of other strategic events around the time of adoption}

A caveat in event study research is that other major events at the same time as the focal event may also cause changes in performance. This is a particular challenge when - as in our study - extremely long windows are examined. To investigate this potential concern, we performed an InfoMedia ${ }^{9}$ search on all our 53 sample firms to identify whether any of the following major strategic events 
had taken place during the year of adoption, or the years before or after: (1) changes in top management; (2) mergers, acquisitions or divestitures; (3) major restructurings or reorganizations. The selection of these particular events was inspired by Kennedy \& Affleck-Graves (2001) based on a trade-off of the expected impact of any confounding effects and the availability of the information. Given that the majority of the firms in the sample are unlisted, privately held companies the level of information about other strategic events such as entry into a new market, the launch of new products or other organic growth initiatives was limited. In order to establish a consistent and comparable approach we therefore decided to stick with the three major events listed above where the data availability is generally considered satisfactory for the purpose of our analysis. The search identified 31 firms where one or more such events had taken place in the relevant time frame: 21 had experienced changes in top management, 17 had experienced some kind of M\&A activity, and 10 had undergone major restructurings. The events were fairly evenly distributed across the three focal years.

Next, we compared these Event firms with the other 22 sample firms that did not experience any of these three events during the relevant time frame (labelled No Event). Our findings are outlined in Table 7. As is evident, we find no significant differences in performance (industryadjusted ROA) between these two sub-samples in any of the years in the analysis ranging from the year before adoption (Pre-adoption -1) to the year 2012. ${ }^{10}$

In summary, we acknowledge the possibility that other major strategic events could have influenced the performance of our sample firms, but find no evidence of a systematic bias in our data.

$<$ INSERT TABLE 7 ABOUT HERE >

\subsection{Matched sample analysis}

The use of industry performance benchmarks in our analyses entails two potential issues. First, the industry benchmark sample most likely contains both CA adopters and non-adopters, which distorts our base for comparison. Second, our industry benchmark approach implicitly assumes that the CA adopters in our sample would perform on par with the rest of the industry if they had not implemented CA. This is arguably a strict assumption. We therefore performed a matched sample analysis to establish a cleaner comparison. Ideally, we wanted to compare our 53 CA adopters with a matched sample of 53 firms that resemble the adopters on all characteristics except the use/nonuse of CA systems for resource allocation purposes. Unfortunately, our only opportunity to identify firms that were definitely non-adopters was from those that indicated in the questionnaire that they 
do not use CA systems. Therefore, we merely applied industry as our matching criteria in order to retain as large a sample as possible. We used 4-digit, 3-digit, and 2-digit NACE codes respectively in order to identify the best possible matches, which left us with a net sample of between 19 and 33 matches over the time period studied ${ }^{11}$. The results of the paired t-tests and Wilcoxon signed rank tests over the years are outlined in Table 8. The results revealed a significant positive coefficient for the second year after adoption. The increase in the difference between adopters and non-adopters during the period from Pre-adoption -1 to Post-adoption +2 was also significant (Difference $=$ $+9.62, t=2.81, p<0.01$ ), and the development in differences between adopters and non-adopters over time generally followed the same pattern as in our analysis vs. industry benchmarks. So, despite the drawbacks of matching based on industry code only, and the lack of statistical power due to the limited amount of suitable matches in our sampling frame, the results of this robustness test of matching CA adopters and non-adopters corroborate our main findings regarding our two hypotheses.

\section{$<$ INSERT TABLE 8 ABOUT HERE >}

\subsection{Influence on different performance measures}

Finally, it is interesting to explore how the adoption of CA systems for resource allocation purposes influences the value drivers underlying ROA. We therefore identified three key drivers of ROA: operating profit margin, asset turnover ratio and market share ${ }^{12}$. The first two were both industry-adjusted for the same reasons as ROA, while we computed market share as the firm's revenues as a proportion of total industry revenues. This way this metric is implicitly adjusted according to industry developments. Figure 2 reports mean industry-adjusted EBIT-margins (Panel $2 a)$, mean industry-adjusted asset turnover ratios (2b), and mean market shares (2c) from one year prior to five years after adoption. All three charts follow a similar pattern to industry-adjusted ROA, albeit with different amplitude and timings. Operating profit margin showed the largest improvement as early as one year after adoption (statistically significant; $p<0.05$ ), but the effect apparently diminished from year 3 onwards. Asset turnover ratio also increased but at a slower pace, reaching its maximum in year 3 before reverting to the same level as before adoption (the increase was marginally insignificant; $p=0.17$ ). There was a marginal increase in market share in year 4, before it then reverted back to pre-adoption levels (not significant; $p=0.81$ ). All this suggests that CA adoption has its greatest impact on operating profit margins, and some effect on asset utilization This is in line with prior research on related strategic management accounting techniques (Kinney \& Wempe, 2002). Interestingly, our data indicate that the effects on operating 
profit margin are more temporary, disappearing again from year 3 onwards. This may be explained by the fact that changes in pricing and product mix will rapidly become visible in the marketplace, and can therefore be more easily imitated by competitors than can the effects of more internal optimization programs. Moreover, the fact that market share remains relatively unaffected could be explained by the levelling out of different factors working in different directions. The effects of changes in pricing and product mix can be expected to influence value market share positively, whereas the trimming of the customer base in terms of down-scaling and/or termination of unprofitable customer relationships can be expected to have an opposite, balancing, effect.

\section{$<$ INSERT FIGURE 2a-c ABOUT HERE >}

\section{Discussion and conclusions}

This paper investigates whether any competitive advantage offered by adopting customer accounting systems for resource allocation purposes will stand the test of time. The results of our event study, robustness tests and additional analyses suggest that management accounting innovations are a source of temporary rather than sustainable competitive advantage. Hence, although we find evidence in favor of a performance effect of implementing CA systems for resource allocation purposes, echoing prior event studies of management accounting techniques such as Activity-Based Costing and The Balanced Scorecard (Crabtree \& DeBusk, 2008; Kennedy \& Affleck-Graves, 2001), our results and robustness tests also imply that adopting firms are unable to sustain this initial above-industry performance over the longer term. CA systems appear to be particularly performance enhancing in the first two years following CA adoption (above-industry ROA of 4-5\%-points), after which the abnormal positive performance differential vis-à-vis industry benchmarks diminishes and CA adopters' financial performance reverts to general industry levels.

We argue that the implementation of management accounting systems such as CA systems for resource allocation purposes leads to competitive advantage as these systems constitute a lowerorder materialization of higher-order dynamic capabilities. Adopting CA systems constitutes one of a number of preconditions for successful customer asset management, and they serve as important facilitators of the reconfiguration and ongoing allocation of firm resources across customer relationships. Our results thus support and extend the findings of prior studies on the much investigated management accounting innovation Activity-Based Costing. Although evidence of the performance effects of ABC is mixed (Banker et al., 2008) a general consensus seems to be emerging that it has an interactive rather than a direct performance effect, either via enabling 
operational improvements (Banker et al., 2008; Ittner, Lanen \& Larcker, 2002; Maiga \& Jacobs, 2008), or strategic initiatives such as Total Quality Management (TQM), Just-In-Time (JIT), or business process engineering (Cagwin \& Barker, 2006; Cagwin \& Bouwman, 2002). So we suggest that future research on management accounting systems' performance effects could benefit from focusing more on how such systems work in conjunction with other (higher order) management capabilities.

Concurrently, we argue that the main reason why using CA systems for resource allocation purposes leads to competitive advantage in the first place is the same reason why that competitive advantage is not sustainable. The materialization of customer asset management capabilities entails the codification of latent knowledge about optimal resource allocation across customer relationships, that allows that knowledge to be transferred beyond organizational boundaries, so facilitating not only internal replication within the organization, but also inter-organizational imitation. Our results therefore contribute to research on the diffusion of managerial innovations by suggesting that fashion motivations - where management fashions are created by such trend-setters as consultants and business schools and subsequently spread across imitating firms (Abrahamson, 1991; Malmi, 1999) - may play an important part in the diffusion of new management accounting innovations, and the concurrent deterioration of abnormal financial returns. At the same time, our evidence about short-term performance effects provides a possible explanation as to why firms seek to adopt such innovations in the first place, which corresponds with the rational adoption motive proposed as the key motivator of first-movers (Malmi, 1999).

From a methodological perspective, our finding that the performance effect of implementing CA systems is time-dependent has implications in the sense that cross-sectional studies will only be meaningful if adopters of the accounting phenomenon being studied are in similar lifecycle stages. If a mix of early and later adopters are studied in the same sample it is less likely that significant performance effects will be detected, which may help explain the mixed results found in prior research e.g., on $\mathrm{ABC}$.

As with any empirical investigation this study has some limitations. First, the size of our sample is small. Fortunately, the t-test procedure applied in our main analyses can be performed even with very small sample sizes. Moreover, small sample sizes is the general premise in survey-based event studies of management accounting system adoptions and performance as it is rarely possible to identify adopters without access to internal data (see e.g., Cagwin \& Bouwman, 2002; Crabtree \& DeBusk, 2008; Kennedy \& Affleck-Graves, 2001; McGowan, 1998).

Second, the use of self-reported CA adoption is potentially problematic, because CA systems can be used in many different ways at different 'intensity levels'. Consequently, the notion of 'the 
use of customer profitability measurement models for resource allocation purposes’ may entail several interpretations. We mitigated this disadvantage by carefully defining the different customer profitability measurement models based on a thorough literature review, and by pre-testing our questionnaire to sharpen our CA definitions. However, we cannot rule out the possibility that CA use is not homogeneous in our sample. More empirical research is therefore warranted to verify our preliminary findings. Larger sample studies could split the sample into subsamples of firms with varying CA adoption degrees. Future case-based research would also be beneficial in order to establish a better understanding of how CA systems are adopted, implemented and diffuse within organizations. In the same vein, it could also be interesting to look into how management accounting innovations travel across firms within a sector or an industry - e.g., via the transfer of people, the involvement of consultants or software vendors etc. - so as to establish a more profound understanding of the imitation process and its links with competitive advantage.

Third, a multitude of factors influence firm performance. One example would be the simultaneous implementation of other management accounting techniques that have been shown to be associated with firm performance such as Activity-Based Costing (e.g., Kennedy \& AffleckGraves 2001) or The Balanced Scorecard (e.g., Crabtree \& DeBusk 2008). Since the ActivityBased Costing technique is often an integrated part of customer profitability models (e.g., Everaert et al., 2008; Kaplan \& Cooper 1998; Noone \& Griffin 1999; Smith \& Dikolli 1995; Guerreiro et al. 2008) the performance effects of CA and ABC are most likely interlinked. Disentangling these effects is a daunting task at best. However, we do attempt to control for some confounding factors such as industry effects by using industry-adjusted performance in our analyses. Our results also turned out to be robust not only to controlling for the implementation of other strategic events around the time of CA adoption but also when controlling for other factors that could be expected to influence firm financial performance in our OLS regression analysis. Therefore, even though we acknowledge that performance improvements could be a consequence of other improvement programs or other factors influencing performance, and that isolating the effect of CA systems completely is utopic, our analyses did not reveal any evidence that contradicts our hypotheses.

Fourth, even though we hypothesize and find support for a cross-sectional temporary performance effect we cannot rule out that the amplitude of this effect varies across business contexts. Future research could pursue contingency-based explanations investigating the moderating effect on the CA-performance relationship of the firm's strategy, structure, environmental uncertainty, customer environment, competitive situation etc.

Finally, causality cannot be precisely determined through observational studies. However, the event study methodology combined with a research design relying on longitudinal data provides 
better opportunities for inferring causal relationships than cross-sectional analyses. Generally, our study supports the notion that more longitudinal research on the impact of management accounting on competitive advantage and firms’ long term performance would be worthwhile.

\section{Acknowledgements}

The authors are grateful for helpful comments and suggestions from Lino Cinquini, Trond Bjørnenak, Frerich Buchholz, Reemda Jaeschke, Christian Ax, Lynette Ryals, Melanie Schneider, seminar participants at NHH in Bergen, and conference participants at The 12th EIASM Manufacturing Accounting Research Conference (MAR) 2014 in Copenhagen and the Nordic Accounting Conference 2014 in Copenhagen, Denmark. A special thanks goes to Jonathan Morgan for competent language editing. We also wish to thank VISMA, and Qvartz for their generous financial support for the data collection. 


\section{Appendix A: Questionnaire}

This study was performed as part of a more comprehensive survey of customer profitability measurement models in Scandinavia. The questionnaire extract presented below only includes the section that is relevant to the current study. Please also note that the online questionnaire applied a conditional logic where informants were guided through the questionnaire depending on their responses to prior questions. Hence, questions Q1-Q3 collectively serve the purpose of identifying CP adopters whereas questions Q5-Q7 collectively serve the purpose of identifying CLV adopters. For CP/CLV adopters only, questions Q4/Q8 serve the purpose of determining the year when the firm implemented CP and/or CLV respectively.

\section{SECTION 1 - USE OF CUSTOMER ACCOUNTING SYSTEMS}

Q1. Are you aware of past/current customer profitability (CP) measurement as a tool for supporting resource allocation decisions across customers?

In responding please consider the following:

Past/current customer profitability (CP) measures the revenues earned from and/or the costs realized in a customer relationship during some specific time period (past or current). Hence, any measurement of past/current customerrelated revenues or profits is considered in this survey as a customer profitability (CP) measurement.

[If “yes” in Q1 - informant is redirected to Q2; If “no” in Q1 - informant is redirected to Q5]

Q2. Is your firm currently using customer profitability (CP) measurement, have you ever tried using it, or have you, at some point over the past three years, considered starting to use it to support resource allocation decisions across customers?

[If “yes” in Q2 - informant is redirected to Q3; If “no” in Q2 - informant is redirected to Q5]

Q3. Please specify the current status on customer profitability (CP) usage at your firm:

a. We're currently considering whether to start using CP at our firm but have not yet reached a decision

b. We're currently running a CP trial which will help decide whether to implement CP at our firm

c. We currently use CP at our firm or have decided to start using it in the near future

d. We have considered to start using CP at our firm but eventually decided not to implement it

e. We have tried using CP in the past but decided to abandon it

[If 'c' in Q3 - informant is redirected to Q4; In all other cases: informant is redirected to Q5]

Q4. Please specify what year you started using customer profitability (CP) at your firm.

Q5. Are you aware of forward-looking customer lifetime value (CLV) estimation as a tool for supporting resource allocation decisions across customers?

In responding please consider the following:

Forward-looking customer lifetime value (CLV) is the present value of expected future revenues, profits or cash flows generated from a customer relationship (in one or more future periods). Hence, estimating customer lifetime value (CLV) involves predicting future customer behaviors and converting these predictions into forecasts of customer revenues, profits or cash flows in future periods.

[If “yes” in Q5 - informant is redirected to Q6; If “no” in Q5 - informant is redirected to Q9]

Q6. Is your firm currently using customer lifetime value (CLV), have you ever tried using it, or have you at some point over the past three years considered starting using it to support resource allocation decisions?

[If “yes” in Q6 - informant is redirected to Q7.; If “no” in Q6 - informant is redirected to Q9]

Q7. Please specify the current status on customer lifetime value (CLV) usage at your firm:

a. We're currently considering whether to start using CLV at our firm but have not yet reached a decision

b. We're currently running a CLV trial which will help decide whether to implement CLV at our firm

c. We currently use CLV or have decided to start using it in the near future

d. We have considered using CLV at our firm but eventually decided not to implement it

$e$. We have tried using CLV in the past but decided to abandon it

[If 'c' in Q7 - informant is redirected to Q8; In all other cases - informant is redirected to Q9]

Q8. Please specify what year you started using customer lifetime value (CLV) at your firm. 


\section{SECTION 2 - PERSONAL INFORMATION}

Q9. Please indicate your primary job function at the firm where you are employed:

a. Chief Executive Officer (CEO) / Business Unit Director / General Manager

b. Country Manager

c. Marketing Executive / Chief Marketing Officer (CMO)

d. Marketing/Sales Vice President (VP)

e. Marketing/Sales Director

f. Business Development Director

g. Marketing/Sales Manager

h. Business Development Manager

i. Do not wish to answer

j. Other 


\section{References}

Abrahamson, E. 1991. Managerial fads and fashions: The diffusion and rejection of innovations. Academy of Management Review 16, 586-612.

Ahrens, T., Chapman, C. S. 2006. New measures in performance management. In A. Bhimani (Ed.), Contemporary issues in management accounting (pp. 1-19). Oxford University Press

Armstrong, J. S., Overton, T. S. 1977. Estimating nonresponse bias in mail Surveys. Journal of Marketing Research 16, 396-402.

Balconi, M., Pozzali, A., Viale, R. 2007. The "codification debate" revisited: A conceptual framework to analyze the role of tacit knowledge in economics. Industrial \& Corporate Change 16, 823-849.

Banker, R. D., Bardhan, I. R., Chen, T. 2008. The role of manufacturing practices in mediating the impact of Activity-Based Costing on plant performance. Accounting, organizations and society 33, $1-19$.

Barber, B. M., Lyon, J. D. 1996. Detecting abnormal operating performance: The empirical power and specification of test statistics. Journal of Financial Economics 41, 359-399.

Barney, J. 1991. Firm resources and sustained competitive advantage. Journal of Management 17, 99-120.

Berger, P. D., Bechwati, N. N. 2001. The allocation of promotion budget to maximize customer equity. Omega 29, 49-61.

Berger, P. D., Bolton, R. N., Bowman, D., Briggs, E., Kumar, V., Parasuraman, A., Terry, C. 2002. Marketing actions and the value of customer assets: A framework for customer asset management. Journal of Service Research 5, 39-54.

Berger, P. D., Nasr, N. I. 1998. Customer lifetime value: Marketing models and applications. Journal of Interactive Marketing 12, 17-30.

Bjørnenak, T. 1997. Diffusion and accounting: The case of ABC in Norway. Management Accounting Research 8, 3-17.

Blattberg, R. C., Deighton, J. 1996. Manage marketing by the customer equity test. Harvard Business Review 74, 136-144.

Blattberg, R. C., Getz, G., Thomas, J. S. 2001. Customer equity. Harvard Business School Press. Boston, MA.

Bolton, R. N., Lemon, K. N., Verhoef, P. C. 2004. The theoretical underpinnings of customer asset management: A framework and propositions for future research. Journal of the Academy of Marketing Science 32, 271-292. 
Cagwin, D., Barker, K. J. 2006. Activity-Based Costing, Total Quality Management and Business Process Reengineering: Their separate and concurrent association with improvement in financial performance. Academy of Accounting and Financial Studies Journal 10, 49-77.

Cagwin, D., Bouwman, M. J. 2002. The association between Activity-Based Costing and improvement in financial performance. Management Accounting Research 13, 1-39.

Capon, N., Farley, J. U., Hoenig, S. 1990. Determinants of financial performance: A meta-analysis. Management Science 36, 1143-1159.

Cepeda, G., Vera, D. 2007. Dynamic capabilities and operational capabilities: A knowledge management perspective. Journal of Business Research 60, 426-437.

Churchill, G. A. 1991. Marketing research: Methodological foundations. Dryden Press. London, UK.

CIMA. 2008. Corporate value creation: Customer value 2008 report, 2-33

Cinquini, L., Tenucci, A. 2010. Strategic management accounting and business strategy: A loose coupling?. Journal of Accounting \& Organizational Change 6, 228-259.

Cooper, R., Kaplan, R. S. 1991. Profit Priorities from Activity-Based Costing. Harvard Business Review 69, 130-135.

Cooper, R., Kaplan, R. S. 1992. Activity-Based Systems: Measuring the Costs of Resource Usage. Accounting Horizons 6, 1-13.

Coff, R. W., Coff, D. C., Eastvold, R. 2006. The knowledge-leveraging paradox: How to achieve ccale without making knowledge imitable. Academy of Management Review 31, 452-465.

Cordeiro, J. J., Kent, D. D. 2001. Do EVA ${ }^{\mathrm{TM}}$ adopters outperform their industry peers? Evidence from security analyst earnings forecasts. American Business Review

Crabtree, A. D., DeBusk, G. K. 2008. The effects of adopting the Balanced Scorecard on shareholder returns. Advances in Accounting 24, 8-15.

Davis, S., Albright, T. 2004. An investigation of the effect of Balanced Scorecard implementation on financial performance. Management accounting research 15, 135-153.

Dillman, D. 1999. Mail and internet surveys: The tailored design method. Wiley. New York, NY.

Dwyer, F. R. 1997. Customer lifetime valuation to support marketing decision making. Journal of Interactive Marketing 11, 6-13.

Easterby-Smith, M., Prieto, I. M. 2008. Dynamic capabilities and knowledge management: An integrative role for learning?. British Journal of Management 19, 235-249.

Easton, G. S., Jarrell, S. L. 1998. The effects of total quality management on corporate performance: An empirical investigation*. The Journal of Business 71, 253-307. 
Eisenhardt, K. M., Martin, J. A. 2000. Dynamic capabilities: What are they?. Strategic Management Journal 21, 1105-1121.

Epstein, M. J., Yuthas, K. 2008. Managing Customer Value. Management Accounting Guideline, CMA/AICPA/CIMA

Everaert, P., Bruggeman, W., Sarens, G., Anderson, S. R., Levant, Y. 2008. Cost modelling in logistics using Time-Driven ABC: Experiences from a wholesaler. International Journal of Distribution \& Logistics Management 38, 172-191.

Foster, G., Young, S. M. 1997. Frontiers of Management Accounting Research. Journal of Management Accounting Research 9, 63-77.

Gordon, L. A., Silvester, K. J. 1999. Stock market reactions to Activity-Based Costing adoptions. Journal of Accounting and Public Policy 18, 229-251.

Granlund, M., Lukka, K. 1998. It is a small world of management accounting practices. Journal of Management Accounting Research 10, 153-179.

Guerreiro, R., Bio, S., Vazquez, E., Merschmann, V. 2008. Cost-to-serve measurement and customer profitability analysis. International Journal of Logistics Management 19, 389-407.

Guilding, C., McManus, L. 2002. The incidence, perceived merit and antecedents of customer accounting: An exploratory note. Accounting, Organizations \& Society 27, 45-59.

Gupta, S., Hanssens, D. M., Hardie, B. G. S., Kahn, W., Kumar, V., Lin, N., Sriram, N. R. S. 2006. Modeling customer lifetime value. Journal of Service Research 9, 139-155.

Gupta, S., Lehmann, D. R. 2005. Managing customers as investments: The strategic value of customers in the long run. Wharton School Publishing. New Jersey.

Haka, S. F., Gordon, L. A., Pinches, G. E. 1985. Sophisticated capital budgeting selection techniques and firm performance. Accounting Review 60, 651.

Håkanson, L. 2007. Creating knowledge: The power and logic of articulation. Industrial \& Corporate Change 16, 51-88.

Heimeriks, K. H., Schijven, M., Gates, S. 2012. Manifestations of higher-order routines: The underlying mechanisms of deliberate learning in the context of postacquisition integration. Academy of Management Journal 55, 703-726.

Hogan, J. E., Lemon, K. N., Rust, R. T. 2002. Customer equity management: Charting new directions for the future of marketing. Journal of Service Research 5, 4-12.

Homburg, C., Droll, M., Totzek, D. 2008. Customer prioritization: Does it pay off, and how should it be implemented?. Journal of Marketing 72, 110-130.

IMA. 2010. Statement on management accounting 67: Customer profitability management, 2-33 
Ittner, C. D., Lanen, W. N., Larcker, D. F. 2002. The association between Activity-Based Costing and manufacturing performance. Journal of Accounting Research 40, 711-726.

Kale, P., Singh, H. 2007. Building firm capabilities through learning: The role of the alliance learning process in alliance capability and firm-level alliance success. Strategic Management Journal 28, 981-1000.

Kaplan, R. S., Cooper, R. 1998. Cost and effect: Using integrated cost systems to drive profitability and performance. Harvard Business School Press. Boston, MA.

Kaplan, R. S., Narayanan, V. G. 2001. Measuring and Managing Customer Profitability. Journal of Cost Management 15, 5-15.

Keil, T. 2004. Building external corporate venturing capability. Journal of Management Studies 41, 799-825.

Kennedy, T., Affleck-Graves, J. 2001. The impact of Activity-Based Costing techniques on firm performance. Journal of management accounting research 13, 19-45.

King, A. W., Zeithaml, C. P. 2001. Competencies and firm performance: Examining the causal ambiguity paradox. Strategic Management Journal 22, 75-99.

Kinney, M. R., Wempe, W. F. 2002. Further evidence on the extent and origins of JIT's profitability effects. The Accounting Review 77, 203-225.

Kogut, B., Zander, U. 1992. Knowledge of the firm, combinative capabilities, and the replication of technology. Organization Science 3, 383-397.

Kumar, V., Shah, D. 2009. Expanding the role of marketing: From customer equity to market capitalization. Journal of Marketing 73, 119-136.

Kumar, V., Shah, D., Venkatesan, R. 2006. Managing retailer profitability - One customer at a time!. Journal of Retailing 82, 277-294.

Kumar, V., Venkatesan, R., Bohling, T., Beckmann, D. 2008. The power of CLV: Managing customer lifetime value at IBM. Marketing Science 27, 585-599.

MacKinlay, A. C. 1997. Event studies in economics and finance. Journal of economic literature 35, 13-39.

Maiga, A. S., Jacobs, F. A. 2008. Extent of ABC use and its consequences. Contemporary accounting research 25, 533-566.

Malmi, T. 1999. Activity-Based Costing diffusion across organizations: An exploratory empirical analysis of Finnish firms. Accounting, Organizations and Society 24, 649-672.

McGowan, A. S. 1998. Perceived benefits of ABCM implementation. Accounting Horizons 12, 3150 . 
McManus, L., Guilding, C. 2008. Exploring the Potential of Customer Accounting: A Synthesis of the Accounting and Marketing Literatures. Journal of Marketing Management 24, 771-795.

Mulhern, F. J. 1999. Customer profitability analysis: Measurement, concentration, and research directions. Journal of Interactive Marketing 13, 25-40.

Niraj, R., Gupta, M., Narasimhan, C. 2001. Customer profitability in a supply chain. Journal of Marketing 65, 1-16.

Noone, B., Griffin, P. 1999. Managing the long-term profit yield from market segments in a hotel environment: A case study on the implementation of customer profitability analysis. International Journal of Hospitality Management 18, 111-128.

Pfeifer, P. E., Haskins, M. E., Conroy, R. M. 2005. Customer lifetime value, customer profitability, and the treatment of acquisition spending. Journal of Managerial Issues 17, 11-25.

Porter, M. E. 1996. What is strategy?. Harvard Business Review 74, 61-78.

Reinartz, W., Krafft, M., Hoyer, W. D. 2004. The Customer Relationship Management Process: Its Measurement and Impact on Performance. Journal of Marketing Research 41, 293-305.

Reinartz, W., Thomas, J. S., Kumar, V. 2005. Balancing acquisition and retention resources to maximize customer profitability. Journal of Marketing 69, 63-79.

Rivkin, J. W. 2001. Reproducing knowledge: replication without imitation at moderate complexity. Organization Science 12, 274-293.

Ryals, L. 2005. Making customer relationship management work: The measurement and profitable management of customer relationships. Journal of Marketing 69, 252-261.

Smith, M., Dikolli, S. 1995. Customer profitability analysis: An Activity-Based Costing approach. Managerial Auditing Journal 10, 3-7.

Srivastava, R. K., Shervani, T. A., Fahey, L. 1998. Market-based assets and shareholder value: A framework for analysis. Journal of Marketing 62, 2-18.

Teece, D. J., Pisano, G., Shuen, A. 1997. Dynamic capabilities and strategic management. Strategic Management Journal 18, 509-533.

Van der Stede, W. A., Young, S. M., Chen, C. X. 2005. Assessing the quality of evidence in empirical management accounting research: The case of survey studies. Accounting, Organizations and Society 30, 655-684.

Vorhies, D. W., Orr, L. M., Bush, V. D. 2011. Improving Customer-Focused Marketing Capabilities and Firm Financial Performance Via Marketing Exploration and Exploitation. Journal of the Academy of Marketing Science 39, 736-756.

White, H. 1980. A Heteroskedasticity-Consistent Covariance Matrix Estimator and a Direct Test for Heteroskedasticity. Econometrica 48, 817-838. 
Winter, S. G. 2003. Understanding dynamic capabilities. Strategic Management Journal 24, 991995.

Zahra, S. A., Sapienza, H. J., Davidsson, P. 2006. Entrepreneurship and dynamic capabilities: A review, model and research agenda. Journal of Management Studies 43, 917-955.

Zander, U., Kogut, B. 1995. Knowledge and the speed of the transfer and imitation of organizational capabilities: An Empirical Test. Organization Science 6, 76-92.

Zollo, M., Singh, H. 2004. Deliberate learning in corporate acquisitions: Post-acquisition strategies and integration capability in U.S. bank mergers. Strategic Management Journal 25, 1233-1256.

Zollo, M., Winter, S. G. 2002. Deliberate learning and the evolution of dynamic capabilities. Organization Science 13, 339-351.

\footnotetext{
${ }^{1}$ This was a part of a larger data collection exercise aimed at investigating CA adoption, usage and design in Scandinavia. An extract of the survey questions relevant for this study is available in Appendix A.

${ }^{2}$ We measured firm size as total revenues in the year when the CA system was adopted.

${ }^{3}$ Our main results also hold when we exclude the financial institutions from our sample.

${ }^{4}$ NACE is the common reference to the Statistical Classification of Economic Activities in the European Community. A complete list of NACE codes can be found on the European Commission's homepage: http://ec.europa.eu/competition/mergers/cases/index/nace_all.html (last accessed March 17, 2015).

${ }^{5}$ Interestingly, mean industry ROA drops in the four years following adoption (see Table 4). The drop is marginally significant (vs. the last year prior to CA adoption) for the first two years after adoption $(p<0.10)$. Moreover, recall that the majority of the adopters in our sample (72\%) adopted CA systems in the years 2004-2008 (see Figure 1). Hence, the drop in mean industry ROA is likely associated with the global financial crisis in 2008. This demonstrates how firms are able to improve relative performance even in times of crisis where the rest of their peers in the industry face declining ROA.
}

${ }^{6}$ Please note that we lose firms from the sample that adopted CA in 2008 (12 obs.) and 2009 (5 obs.) when we look at post adoption performance 4-5 years after the year of adoption as no data is yet available on the full time horizon. This explains why $\mathrm{N}$ drops to 48 observations in Post-adoption +4 and 37 observations in Post-adoption +5 . Performance in the year 2012 consists of a mix of different 'CA maturity' lengths, although all observations in this sample will be at least three years post adoption. The average length of 'CA maturity' in 2012 is 6.7 years, so - on average - the 2012 indicator will be over a longer time horizon than Post-adoption +5 .

${ }^{7}$ Industry concentration was only available from 2009. We therefore decided to use the same industry concentration across time. This is reasonable as the concentration ratio in industries is generally stable over longer time periods. The remaining control variables all vary over time.

\footnotetext{
${ }^{8}$ It can be argued that firms' ability to implement the new differentiated pricing and resource allocation strategies across customers facilitated by the CA system is associated with the firm's market power. Hence, firms with higher market share could potentially reap larger financial benefits of CA adoption than firms with smaller market share. We tested this relationship by adding the interaction between CA and MSHARE (CA*MSHARE) in our model. The results showed no significant effects of the interaction term but the economic significance of our focal variable (CA adoption) increased in this revised model.

${ }^{9}$ InfoMedia is a Danish news media service that provides access to more than 60 million articles from a wide range of Danish newspapers, journals etc.
} 
${ }^{10}$ We also repeated the event study on the sample of firms that experienced no other major strategic events around the time of CA adoption. This analysis generally supported our main conclusions with statistically significant negative long term effects ( $p<0.05$ from year 2 to year 5 post adoption; two-tailed tests) and positive but insignificant short term performance effects ( $p=0.22$ in year 1 post adoption; $p=0.14$ in year 2 post adoption; two-tailed tests). Given that the sample only includes 22 observations the less significant results observed for the short term effects are likely explained by the low statistical power in these tests.

${ }^{11}$ Given that data were collected in the fall and winter 2010/11, we had to exclude data for the year 2012 as we cannot rule out that the declared non-adopters in our sample adopted CA after our data collection .

${ }^{12}$ Kennedy \& Affleck-Graves (2001) also found that ABC adoption impacted financial leverage in the sense that adopters took on more debt than non-adopters. In order to examine whether a similar effect can be found when considering CA adoption we tested for this relationship but found no indication that CA adoption influences financial leverage. 
An investigation of customer accounting systems as a source of sustainable competitive advantage

Figures 


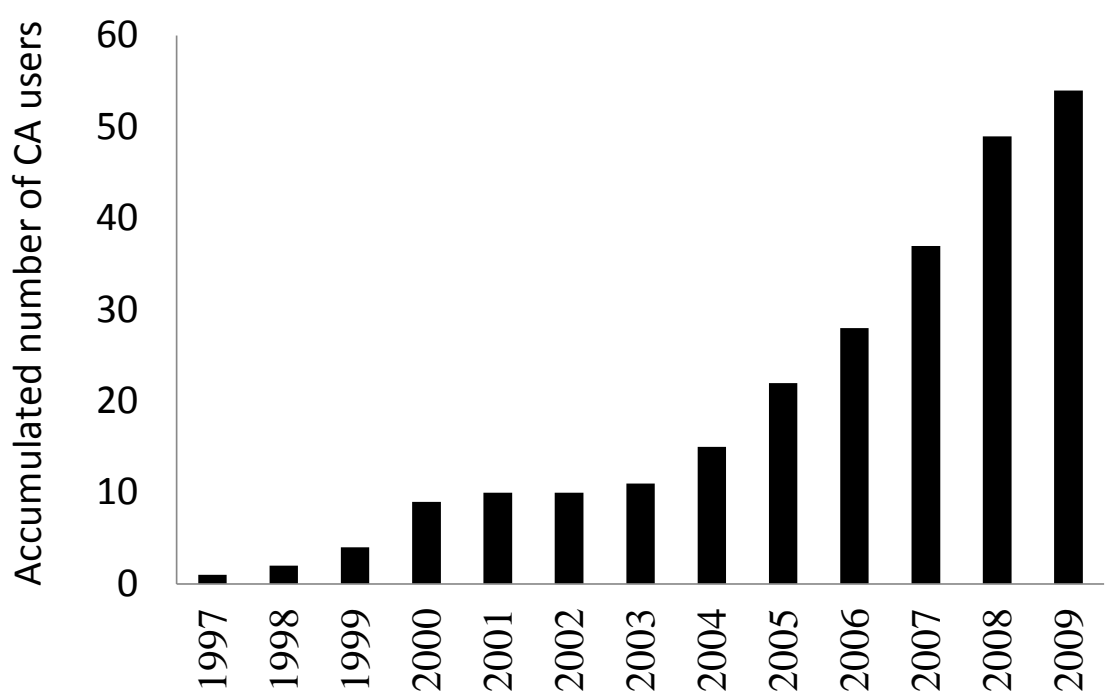

Fig. 1. What year was CA introduced? 


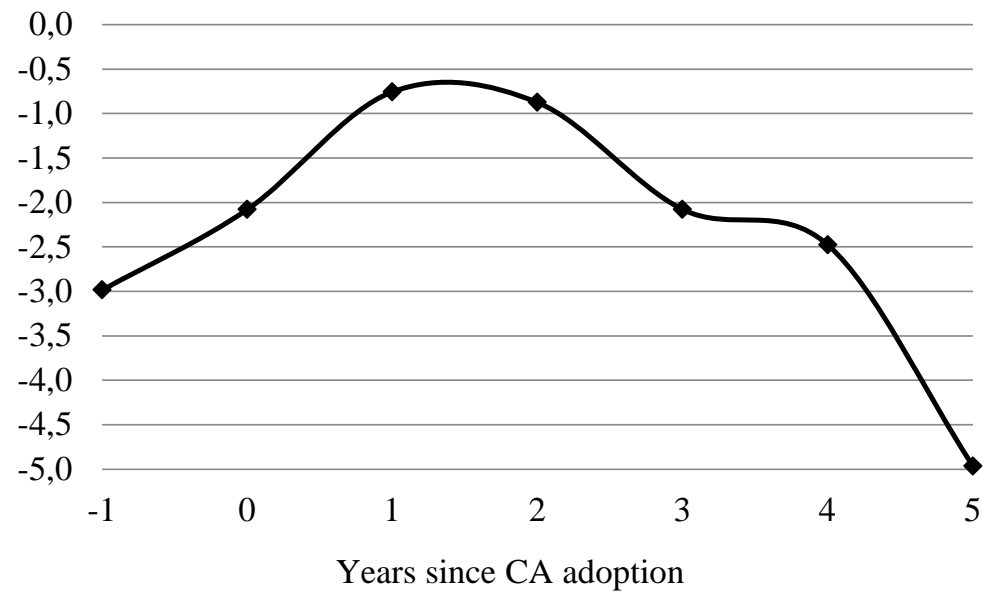

Fig. 2a. Mean industry-adjusted EBIT-margin for CA adopters from one year prior to adoption to five years after adoption

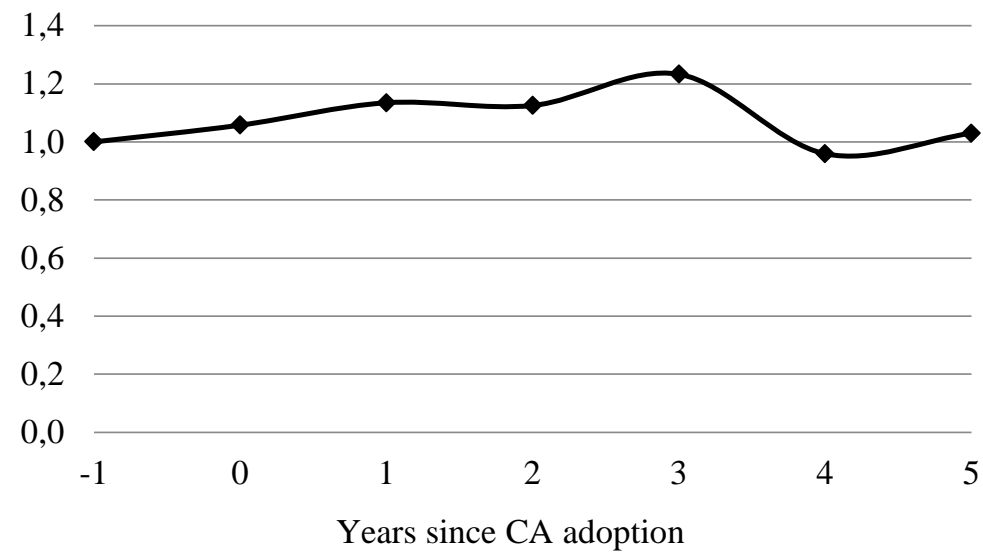

Fig. 2b. Mean industry-adjusted asset turnover ratio for CA adopters from one year prior to adoption to five years after adoption ( $\mathrm{N}=49$ in $\mathrm{Y}-1$ to $\mathrm{Y3} ; \mathrm{N}=44$ in $\mathrm{Y} 4 ; \mathrm{N}=35$ in $\mathrm{Y} 5)$

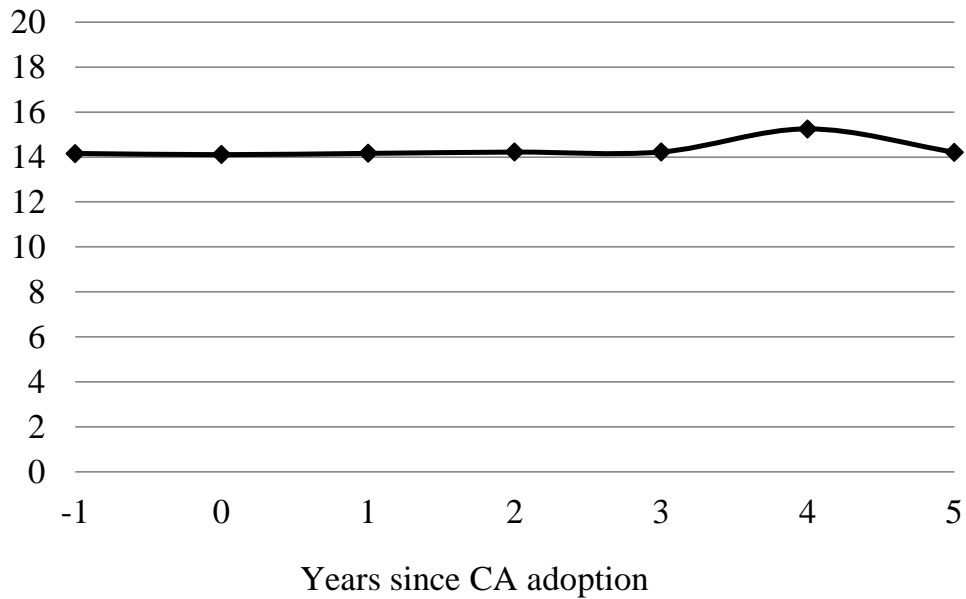

Fig. 2c. Mean market share for CA adopters from one year prior to adoption to five years after adoption

( $\mathrm{N}=47$ in $\mathrm{Y}-1$ to $\mathrm{Y} 3 ; \mathrm{N}=43$ in $\mathrm{Y} 4 ; \mathrm{N}=33$ in $\mathrm{Y} 5)$ 
An investigation of customer accounting systems as a source of sustainable competitive advantage

Tables 
Table 1

Sample composition

(A) Industry sector

No. obs. $\quad \%$

Manufacturing

$18 \quad 33$

(NACE Section C)

Wholesaling and retail trade

$14 \quad 26$

(NACE Section G)

Services

$7 \quad 13$

(NACE Sections I, J, M, N, R)

Transportation and storage

$6 \quad 11$

(NACE Section $\mathrm{H}$ )

Financial institutions and real estate

$4 \quad 9$

(NACE Sections K, L)

Utilities

36

(NACE Sections D, E)

Construction

12

(NACE Section F)

Total

$53 \quad 100$

(B) Firm revenue (DKK mio.)

No. obs. \%

$<250$

$4 \quad 8$

250 - 499

$9 \quad 17$

$500-749$

$14 \quad 26$

750 - 999

$7 \quad 13$

$1,000-2,499$

$9 \quad 17$

$2,500-4,999$

$6 \quad 11$

$5,000<$

48

Total

$53 \quad 100$

(C) Informant position

No. obs. \%

\begin{tabular}{lrr} 
Sales/Marketing Executive & 16 & 30 \\
CEO or General Manager & 9 & 17 \\
Business Development Director/Mgr. & 5 & 9 \\
Sales/Marketing Manager & 4 & 8 \\
CFO or Finance Manager & 4 & 8 \\
Other & 1 & 2 \\
No Answer & 14 & 26 \\
Total & 53 & 100 \\
\hline
\end{tabular}


Table 2

Number of firms per benchmark industry over time

\begin{tabular}{|c|c|c|c|c|}
\hline \multirow[b]{2}{*}{$\begin{array}{l}\text { Industry } \\
\text { (NACE } \\
\text { 3-digit) }\end{array}$} & \multirow[b]{2}{*}{$\begin{array}{l}\text { No. of } \\
\text { firms in } \\
\text { sample }\end{array}$} & \multicolumn{3}{|c|}{ Industry } \\
\hline & & $\begin{array}{l}\text { Mean no. } \\
\text { of firms in } \\
\text { industry }\end{array}$ & $\begin{array}{l}\text { Min. firms } \\
\text { in industry }\end{array}$ & $\begin{array}{l}\text { Max. firms } \\
\text { in industry }\end{array}$ \\
\hline 101 & 1 & 15 & 12 & 18 \\
\hline 108 & 1 & 29 & 21 & 37 \\
\hline 110 & 1 & 21 & 19 & 22 \\
\hline 139 & 1 & 24 & 12 & 37 \\
\hline 172 & 3 & 18 & 14 & 23 \\
\hline 181 & 1 & 92 & 50 & 128 \\
\hline 204 & 1 & 8 & 6 & 9 \\
\hline 205 & 1 & 7 & 5 & 10 \\
\hline 211 & 1 & 9 & 7 & 10 \\
\hline 222 & 2 & 60 & 34 & 79 \\
\hline 244 & 1 & 4 & 3 & 6 \\
\hline 261 & 1 & 17 & 12 & 22 \\
\hline 282 & 1 & 64 & 52 & 80 \\
\hline 289 & 1 & 62 & 46 & 83 \\
\hline 325 & 1 & 34 & 27 & 45 \\
\hline 351 & 2 & 209 & 148 & 243 \\
\hline 352 & 1 & 17 & 12 & 22 \\
\hline 432 & 1 & 397 & 273 & 570 \\
\hline 451 & 1 & 252 & 170 & 329 \\
\hline 452 & 1 & 206 & 158 & 275 \\
\hline 453 & 1 & 33 & 25 & 38 \\
\hline 463 & 1 & 186 & 143 & 244 \\
\hline 464 & 5 & 420 & 319 & 576 \\
\hline 465 & 2 & 151 & 110 & 185 \\
\hline 467 & 1 & 291 & 202 & 372 \\
\hline 475 & 1 & 94 & 74 & 125 \\
\hline 477 & 1 & 326 & 238 & 431 \\
\hline 492 & 1 & 2 & 2 & 2 \\
\hline 501 & 2 & 29 & 20 & 45 \\
\hline 502 & 2 & 99 & 44 & 168 \\
\hline 522 & 1 & 229 & 185 & 252 \\
\hline 613 & 1 & 1 & 1 & 2 \\
\hline 619 & 1 & 25 & 21 & 27 \\
\hline 620 & 2 & 659 & 333 & 846 \\
\hline 641 & 2 & 31 & 10 & 59 \\
\hline 651 & 1 & 18 & 8 & 43 \\
\hline 683 & 1 & 889 & 730 & 990 \\
\hline 731 & 1 & 180 & 143 & 212 \\
\hline 791 & 1 & 56 & 49 & 63 \\
\hline 920 & 1 & 19 & 14 & 30 \\
\hline TOTAL & 53 & 132 & 1 & 990 \\
\hline
\end{tabular}


Table 3

Prior event studies on the financial effects of adopting strategic management accounting techniques

\begin{tabular}{|c|c|c|c|c|c|c|c|c|c|c|}
\hline \multirow[t]{2}{*}{ Study } & \multirow[t]{2}{*}{ Journal } & \multirow[t]{2}{*}{ Topic* } & \multirow{2}{*}{$\begin{array}{l}\text { Event } \\
\text { study }\end{array}$} & \multirow{2}{*}{$\begin{array}{c}\text { Effect } \\
\text { horizon }\end{array}$} & \multirow{2}{*}{$\begin{array}{l}\text { Long term } \\
\text { sustaina- } \\
\text { bility }\end{array}$} & \multicolumn{2}{|c|}{ Design } & \multirow{2}{*}{$\begin{array}{c}\text { Sample } \\
\text { size } \\
(\mathrm{N})\end{array}$} & \multirow{2}{*}{$\begin{array}{c}\text { Dichotomous } \\
\text { independent } \\
\text { variable }\end{array}$} & \multirow{2}{*}{$\begin{array}{l}\text { Dependent } \\
\text { variable }\end{array}$} \\
\hline & & & & & & $\begin{array}{l}\text { Matched } \\
\text { pair }\end{array}$ & $\begin{array}{c}\text { Industry } \\
\text { benchmark }\end{array}$ & & & \\
\hline Haka et al. (1985) & The Accounting Review & $\begin{array}{c}\text { Capital } \\
\text { Budgeting }\end{array}$ & Yes & 4 years & No & Yes & No & 30 & Yes & Market returns \\
\hline $\begin{array}{l}\text { Easton and } \\
\text { Jarrell (1998) }\end{array}$ & Journal of Business & TQM & Yes & 5 years & No & Yes & No & 108 & $(\text { Yes) })^{* *}$ & $\begin{array}{c}\text { Market returns / } \\
\text { Accounting } \\
\text { measures }\end{array}$ \\
\hline $\begin{array}{l}\text { Gordon and } \\
\text { Silvester (1999) }\end{array}$ & $\begin{array}{l}\text { Journal of Accounting } \\
\text { and Public Policy }\end{array}$ & $\mathrm{ABC}$ & Yes & 1 year & No & Yes & No & 10 & Yes & Market returns \\
\hline $\begin{array}{l}\text { Cordeiro and Kent } \\
\text { (2001) }\end{array}$ & $\begin{array}{l}\text { American Business } \\
\text { Review }\end{array}$ & EVA & Yes & $\begin{array}{l}\text { Cross- } \\
\text { sectional }\end{array}$ & No & (Yes) & Yes & 63 & Yes & $\begin{array}{l}\text { Analyst } \\
\text { forecasts }\end{array}$ \\
\hline $\begin{array}{l}\text { Kennedy and } \\
\text { Affleck-Graves } \\
\text { (2001) }\end{array}$ & $\begin{array}{l}\text { Journal of Management } \\
\text { Accounting Research }\end{array}$ & $\mathrm{ABC}$ & Yes & 3 years & No & Yes & No & $33-37$ & Yes & $\begin{array}{c}\text { Market returns / } \\
\text { Accounting } \\
\text { measures }\end{array}$ \\
\hline $\begin{array}{l}\text { Kinney and } \\
\text { Wempe (2002) }\end{array}$ & The Accounting Review & JIT & Yes & 3 years & No & Yes & No & 201 & Yes & $\begin{array}{l}\text { Accounting } \\
\text { measures }\end{array}$ \\
\hline $\begin{array}{l}\text { Crabtree and } \\
\text { DeBusk (2008) }\end{array}$ & Advances in Accounting & BSC & Yes & 3 years & No & Yes & No & $38-42$ & Yes & $\begin{array}{c}\text { Market returns / } \\
\text { Accounting } \\
\text { measures }\end{array}$ \\
\hline Current study & & CA & Yes & 5 years & Yes & Yes & Yes & 53 & Yes & $\begin{array}{l}\text { Accounting } \\
\text { measures }\end{array}$ \\
\hline
\end{tabular}

*Topic abbreviations: TQM = 'Total Quality Management'; ABC = 'Activity-Based Costing'; EVA = 'Economic Value Added'; JIT = 'Just-in-time'; BSC = 'Balanced Scorecard'; CA = 'Customer Accounting'

**Adopters divided into less v. more advanced 
Table 4

Pre- and post adoption performance for CA users vs. industry benchmarks

\begin{tabular}{|c|c|c|c|c|c|c|c|c|c|c|c|c|c|}
\hline \multirow[b]{2}{*}{ Year } & \multirow[b]{2}{*}{$\mathrm{N}$} & \multicolumn{2}{|c|}{$\begin{array}{c}\mathrm{ROA} / \mathrm{E} \\
\text { CA adopters }\end{array}$} & \multicolumn{2}{|c|}{$\begin{array}{l}\mathrm{ROA} / \mathrm{E} \\
\text { Industry }\end{array}$} & \multirow{2}{*}{$\begin{array}{l}\text { Mean } \\
\text { Diff. }\end{array}$} & \multirow{2}{*}{$\begin{array}{l}\text { Stud. } \\
\text { t-value }\end{array}$} & \multirow{2}{*}{$\begin{array}{c}\mathrm{ROA} / \mathrm{E} \\
\mathrm{CA} \\
\text { adopters } \\
\text { Median }\end{array}$} & \multirow{2}{*}{$\begin{array}{l}\text { ROA/E } \\
\text { Industry }\end{array}$} & \multirow{2}{*}{$\begin{array}{l}\text { Median } \\
\text { Diff. }\end{array}$} & \multicolumn{2}{|c|}{$\begin{array}{l}\text { Wilcoxon } \\
\text { signed rank }\end{array}$} & \multirow{2}{*}{$\begin{array}{c}\text { Prop. of } \\
\text { CA } \\
\text { adopters > } \\
\text { industry }\end{array}$} \\
\hline & & Mean & SD & Mean & SD & & & & & & S-value & $p$-value & \\
\hline Pre-adoption -2 & 52 & 9.13 & 23.15 & 8.81 & 14.59 & 0.32 & 0.19 & 6.75 & 5.88 & 0.87 & -20.0 & 0.8575 & 0.5192 \\
\hline Pre-adoption -1 & 53 & 9.01 & 21.56 & 8.86 & 13.64 & 0.15 & 0.10 & 6.61 & 6.87 & -0.26 & -31.5 & 0.7833 & 0.5094 \\
\hline Adoption & 53 & 9.86 & 24.66 & 8.30 & 15.47 & 1.56 & 0.72 & 5.43 & 6.41 & -0.98 & -21.5 & 0.8511 & 0.5283 \\
\hline Post-adoption +1 & 53 & 10.43 & 21.03 & 6.45 & 16.64 & 3.98 & $2.47 * *$ & 7.40 & 6.38 & 1.02 & 233.5 & $0.0375^{* *}$ & 0.5849 \\
\hline Post-adoption +2 & 53 & 11.05 & 20.10 & 6.02 & 17.59 & 5.03 & $2.72 * * *$ & 6.83 & 5.66 & 1.17 & 247.5 & $0.0270^{* *}$ & 0.6226 \\
\hline Post-adoption +3 & 53 & 9.71 & 23.32 & 6.70 & 17.45 & 3.01 & 1.43 & 6.54 & 6.83 & -0.29 & 131.5 & 0.2481 & 0.5472 \\
\hline Post-adoption +4 & 48 & 8.75 & 20.08 & 7.23 & 18.28 & 1.52 & 0.76 & 6.53 & 6.30 & 0.23 & -33.0 & 0.7389 & 0.4375 \\
\hline Post-adoption +5 & 37 & 8.16 & 22.99 & 9.95 & 21.68 & -1.79 & -0.94 & 5.93 & 7.54 & -1.61 & -62.5 & 0.3528 & 0.3611 \\
\hline Year 2012 & 53 & 7.89 & 20.13 & 8.86 & 18.11 & -0.97 & -0.59 & 6.08 & 6.40 & -0.32 & -82.5 & 0.4704 & 0.4528 \\
\hline
\end{tabular}

*, **, *** Statistically significant at 0.10, 0.05 and 0.01 respectively; Two-tailed tests 
Table 5

Post adoption industry-adjusted performance for CA users in the short and the longer term

\begin{tabular}{|c|c|c|c|c|c|c|c|c|c|}
\hline \multirow[b]{2}{*}{ Description } & \multirow[b]{2}{*}{$\mathrm{N}$} & \multicolumn{2}{|c|}{$\begin{array}{c}\text { Industry-adjusted } \\
\text { ROA/E }\end{array}$} & \multirow{2}{*}{$\begin{array}{c}\text { Mean } \\
\text { Difference }\end{array}$} & \multirow{2}{*}{$\begin{array}{l}\text { Stud. } \\
\text { t-value }\end{array}$} & \multirow{2}{*}{$\begin{array}{c}\text { Industry- } \\
\text { adjusted } \\
\text { ROA/E } \\
\text { Median }\end{array}$} & \multirow{2}{*}{$\begin{array}{c}\text { Median } \\
\text { Difference }\end{array}$} & \multicolumn{2}{|c|}{$\begin{array}{l}\text { Wilcoxon } \\
\text { signed rank }\end{array}$} \\
\hline & & Mean & SD & & & & & S-value & $p$-value \\
\hline Post adoption +1 & 53 & 3.98 & 11.76 & & & 1.12 & & & \\
\hline \multicolumn{10}{|c|}{ Long term benchmarks } \\
\hline Post-adoption +4 & 48 & 1.52 & 13.81 & -2.46 & -1.26 & -0.54 & -1.66 & -234.0 & $0.0148 * *$ \\
\hline Post-adoption +5 & 37 & -1.79 & 11.52 & -5.77 & $-2.13 * *$ & -1.60 & -2.72 & -130.5 & $0.0475^{* *}$ \\
\hline Year 2012 & 53 & -0.97 & 11.87 & -4.95 & $-2.80 * * *$ & -0.65 & -1.77 & -280.5 & $0.0116^{* *}$ \\
\hline Post adoption +2 & 53 & 5.03 & 13.47 & & & 0.76 & & & \\
\hline \multicolumn{10}{|c|}{ Long term benchmarks } \\
\hline Post-adoption +4 & 48 & 1.52 & 13.81 & -3.51 & -1.54 & -0.54 & -1.30 & -266.0 & $0.0051^{* * *}$ \\
\hline Post-adoption +5 & 37 & -1.79 & 11.52 & -6.82 & $-2.58 * *$ & -1.60 & -2.36 & -163.5 & $0.0178 * *$ \\
\hline Year 2012 & 53 & -0.97 & 11.87 & -6.00 & $-2.93 * * *$ & -0.65 & -1.41 & -262.5 & $0.0186^{* *}$ \\
\hline Post adoption +3 & 53 & 3.01 & 15.30 & & & 1.72 & & & \\
\hline \multicolumn{10}{|c|}{ Long term benchmarks } \\
\hline Post-adoption +4 & 48 & 1.52 & 13.81 & -1.49 & -1.39 & -0.54 & -2.26 & -195.0 & $0.0443^{* *}$ \\
\hline Post-adoption +5 & 37 & -1.79 & 11.52 & -4.80 & $-2.50 * *$ & -1.60 & -3.32 & -136.5 & $0.0376^{* *}$ \\
\hline Year 2012 & 53 & -0.97 & 11.87 & -3.98 & $-1.97^{*}$ & -0.65 & -2.37 & -143.0 & 0.1442 \\
\hline
\end{tabular}

*, **, *** Statistically significant at 0.10, 0.05 and 0.01 respectively; Two-tailed tests 
Table 6

OLS regressions for each of the years 1-5 following CA adoption

\begin{tabular}{|c|c|c|c|c|c|}
\hline $\begin{array}{l}\text { Dependent variable: Industry-adjusted } \\
\text { ROA }\end{array}$ & $\begin{array}{l}\text { Post- } \\
\text { Adoption } \\
\quad+1\end{array}$ & $\begin{array}{l}\text { Post- } \\
\text { Adoption } \\
+2\end{array}$ & $\begin{array}{l}\text { Post- } \\
\text { Adoption } \\
+3\end{array}$ & $\begin{array}{l}\text { Post- } \\
\text { Adoption } \\
+4\end{array}$ & $\begin{array}{l}\text { Post- } \\
\text { Adoption } \\
+5\end{array}$ \\
\hline Intercept & $\begin{array}{l}12.09 \\
(0.88)\end{array}$ & $\begin{array}{l}15.43 \\
(1.10)\end{array}$ & $\begin{array}{l}5.01 \\
(0.35)\end{array}$ & $\begin{array}{c}0.47 \\
(0.04)\end{array}$ & $\begin{array}{c}6.37 \\
(0.51)\end{array}$ \\
\hline$C A$ & $\begin{array}{l}3.00 * \\
(1.63)\end{array}$ & $\begin{array}{l}2.69 * \\
(1.39)\end{array}$ & $\begin{array}{l}1.32 \\
(0.62)\end{array}$ & $\begin{array}{c}0.40 \\
(0.22)\end{array}$ & $\begin{array}{l}-1.70 \\
(-0.76)\end{array}$ \\
\hline INDCONC & $\begin{array}{l}0.39 * * * \\
(4.54)\end{array}$ & $\begin{array}{c}0.33^{* * *} \\
(4.57)\end{array}$ & $\begin{array}{c}0.37 * * * \\
(4.66)\end{array}$ & $\begin{array}{c}0.36 * * * \\
(5.12)\end{array}$ & $\begin{array}{c}0.30 * * * \\
(4.17)\end{array}$ \\
\hline$M_{S H A R E}$ & $\begin{array}{c}0.09 \\
(1.23)\end{array}$ & $\begin{array}{l}0.12 * \\
(1.57)\end{array}$ & $\begin{array}{l}0.11^{*} \\
(1.39)\end{array}$ & $\begin{array}{c}0.08 \\
(1.15)\end{array}$ & $\begin{array}{c}0.08 \\
(1.15)\end{array}$ \\
\hline $\mathrm{GROWTH}_{t}$ & $\begin{array}{l}0.06 * * \\
(1.72)\end{array}$ & $\begin{array}{l}0.04 * \\
(1.49)\end{array}$ & $\begin{array}{l}0.09 * \\
(1.51)\end{array}$ & $\begin{array}{l}0.10^{* *} \\
(2.06)\end{array}$ & $\begin{array}{c}0.12 * * * \\
(2.57)\end{array}$ \\
\hline$S I Z E_{t}$ & $\begin{array}{l}-1.31 \\
(-1.45)\end{array}$ & $\begin{array}{l}-1.57^{*} \\
(-1.66)\end{array}$ & $\begin{array}{c}-1.03 \\
(-1.02)\end{array}$ & $\begin{array}{c}-0.54 \\
(-0.59)\end{array}$ & $\begin{array}{c}-0.74 \\
(-0.84)\end{array}$ \\
\hline$E_{Q R A T I O}$ & $\begin{array}{c}-0.01 \\
(-0.20)\end{array}$ & $\begin{array}{c}0.01 \\
(0.22)\end{array}$ & $\begin{array}{c}0.07 \\
(1.13)\end{array}$ & $\begin{array}{c}0.03 \\
(0.49)\end{array}$ & $\begin{array}{c}-0.05 \\
(-0.66)\end{array}$ \\
\hline$N$ & 132 & 132 & 132 & 129 & 118 \\
\hline$R$-squared & 0.23 & 0.18 & 0.21 & 0.23 & 0.18 \\
\hline Adjusted $R$-squared & 0.19 & 0.14 & 0.17 & 0.19 & 0.13 \\
\hline F-statistic & 6.28 & 4.64 & 5.62 & 6.15 & 4.00 \\
\hline Prob. (F-statistic) & $<0.01$ & $<0.01$ & $<0.01$ & $<0.01$ & $<0.01$ \\
\hline
\end{tabular}

*, **, *** Statistically significant at 0.10, 0.05 and 0.01 respectively;

One-tailed tests (except for SIZE); t-values in brackets;

Note: Heteroscedasticity consistent standard errors applied (White 1980) 
Table 7

Robustness: Comparison of industry-adjusted ROA for firms with / without major events around the time of adoption

\begin{tabular}{|c|c|c|c|c|c|c|c|c|c|c|}
\hline \multirow[b]{2}{*}{ Year } & \multicolumn{3}{|c|}{$\begin{array}{l}\text { No Event Firms } \\
\text { Industry-adj. ROA }\end{array}$} & \multicolumn{3}{|c|}{$\begin{array}{c}\text { Event Firms } \\
\text { Industry-adj. ROA }\end{array}$} & \multirow{2}{*}{$\begin{array}{c}\begin{array}{c}\text { Mean } \\
\text { difference } \\
\text { t-test }^{\mathrm{a}}\end{array} \\
p \\
p\end{array}$} & \multicolumn{2}{|c|}{$\begin{array}{c}\text { Industry-adj. ROA } \\
\text { Medians }\end{array}$} & \multirow{2}{*}{$\begin{array}{c}\begin{array}{c}\text { Median } \\
\text { difference } \\
\text { z-test }^{\mathrm{b}}\end{array} \\
p\end{array}$} \\
\hline & $\mathrm{N}$ & Mean & SD & $\mathrm{N}$ & Mean & SD & & No event & event & \\
\hline Pre-adoption -1 & 22 & 2.24 & 12.98 & 31 & -1.33 & 10.02 & 0.2874 & -0.70 & 0.58 & 0.5966 \\
\hline Adoption & 22 & 2.72 & 13.1 & 31 & 0.72 & 17.47 & 0.6360 & -0.56 & 1.02 & 0.6863 \\
\hline Post-adoption +1 & 22 & 4.44 & 12.07 & 31 & 3.66 & 11.72 & 0.8161 & 1.02 & 1.12 & 0.8928 \\
\hline Post-adoption +2 & 22 & 5.43 & 13.42 & 31 & 4.74 & 13.72 & 0.8556 & 1.23 & 0.73 & 0.9066 \\
\hline Post-adoption +3 & 22 & 4.08 & 16.10 & 31 & 2.24 & 14.93 & 0.6746 & 1.49 & 1.79 & 0.9353 \\
\hline Post-adoption +4 & 19 & 2.21 & 12.95 & 29 & 1.07 & 14.56 & 0.7774 & -0.08 & -1.03 & 0.4643 \\
\hline Post-adoption +5 & 18 & -1.09 & 9.29 & 19 & -1.88 & 13.53 & 0.8413 & -2.59 & -1.49 & 0.7962 \\
\hline Year 2012 & 22 & -0.10 & 11.74 & 31 & -1.59 & 12.12 & 0.6550 & -0.34 & -1.08 & 0.7658 \\
\hline
\end{tabular}

${ }^{a}$ Using t-test for equality of two means (two-sided; unpaired)

${ }^{b}$ Using Wilcoxon test for equality of two medians (two-sided; unpaired) 
Table 8

Robustness: Pre- and post adoption performance for CA users vs. matched sample of non-users

\begin{tabular}{|c|c|c|c|c|c|c|c|c|c|c|c|c|c|}
\hline \multirow[b]{2}{*}{ Year } & \multirow[b]{2}{*}{$\mathrm{N}$} & \multicolumn{2}{|c|}{$\begin{array}{l}\mathrm{ROA} / \mathrm{E} \\
\mathrm{CA} \text { firms }\end{array}$} & \multicolumn{2}{|c|}{$\begin{array}{c}\mathrm{ROA} / \mathrm{E} \\
\text { matched sample }\end{array}$} & \multirow{2}{*}{$\begin{array}{l}\text { Mean } \\
\text { Diff. }\end{array}$} & \multirow{2}{*}{$\begin{array}{l}\text { Stud. } \\
\text { t-value }\end{array}$} & \multirow{2}{*}{$\begin{array}{c}\text { ROA/E } \\
\text { CA } \\
\text { Firms } \\
\text { Median }\end{array}$} & \multirow{2}{*}{$\begin{array}{c}\text { ROA/E } \\
\text { matched } \\
\text { sample } \\
\text { Median }\end{array}$} & \multirow{2}{*}{$\begin{array}{l}\text { Median } \\
\text { Diff. }\end{array}$} & \multicolumn{2}{|c|}{$\begin{array}{l}\text { Wilcoxon } \\
\text { signed rank }\end{array}$} & \multirow{2}{*}{$\begin{array}{c}\text { Prop. of } \\
\text { CA } \\
\text { firms }> \\
\text { matched }\end{array}$} \\
\hline & & Mean & SD & Mean & SD & & & & & & S-value & $p$-value & \\
\hline Pre-adoption -1 & 33 & 7.09 & 11.63 & 11.49 & 12.64 & -4.40 & -1.66 & 7.46 & 7.83 & -0.37 & -72.5 & 0.20 & 0.4242 \\
\hline Adoption & 33 & 8.48 & 19.27 & 10.02 & 12.51 & -1.54 & -0.45 & 6.40 & 5.36 & 1.04 & -30.5 & 0.59 & 0.4545 \\
\hline Post-adoption +1 & 33 & 9.75 & 10.86 & 7.19 & 12.45 & 2.56 & 0.87 & 7.78 & 5.89 & 1.89 & 27.5 & 0.63 & 0.5454 \\
\hline Post-adoption +2 & 33 & 11.05 & 10.07 & 5.84 & 10.83 & 5.21 & $2.06 * *$ & 8.55 & 6.04 & 2.51 & 102.5 & $0.07 *$ & 0.6667 \\
\hline Post-adoption +3 & 30 & 9.51 & 13.51 & 6.29 & 8.00 & 3.22 & 1.05 & 7.77 & 5.33 & 2.44 & 33.5 & 0.50 & 0.4667 \\
\hline Post-adoption +4 & 23 & 5.71 & 11.00 & 5.06 & 8.33 & 0.65 & 0.29 & 6.82 & 4.76 & 2.06 & 9.0 & 0.79 & 0.5652 \\
\hline Post-adoption +5 & 19 & 5.48 & 9.80 & 7.39 & 6.70 & -1.91 & -0.77 & 5.57 & 7.91 & -2.34 & -26.0 & 0.31 & 0.3684 \\
\hline
\end{tabular}

*, **, *** Statistically significant at 0.10, 0.05 and 0.01 respectively; Two-tailed tests

Note: All observations in 2012 excluded due to lack of knowledge of CA adoption status that

year 